\title{
Examination of Relationship between Work Motivation and Work Performance of the Education Workers
}

\author{
Yusuf OZCAN \\ Institute Business Management and Law, Russia
}

(C) The Author(s) 2018

\begin{abstract}
It is attempted to determine the relationships between the work motivations and work performances of the employees in the field of education. In this study, the relationship between work motivation and work performance of education employees was examined according to some variables. The research is a descriptive study based on relational screening model. As a result of the study, the team cohesion and adherence to the institution were found higher than the male employees. The performance levels of the work performance scale were lower than female employees'. Meaningful differences were found in goodness of employees between the ages of 20 and 30 in the dimensions of team cohesion, job integration and commitment to the institution from the sub-dimensions of work motivation scale according to the age of the employees. These results were discussed with the related literature and suggestions were made for the researchers.
\end{abstract}

C2018.All rights reserved

\section{ARTICLE HISTORY}

Received: 29/04/2018

Accepted: 27/07/2018

Published online: 05/10/2018
KEYWORDS

Work motivation, work motivation, education worker 


\section{Introduction}

The education process is a social period and lets the development of the person with a selected and controlled environmental effect. Education is; physical, emotional, mental and social development realized in the most appropriate way to that related society (Öztürk, 2006). The main characteristic that separates the school from other institutions is that it works on human and differentiation of it (Danış, 2009).

One of the most important elements of the school is the teachers. In the efficiency of the schools which are the organizations of our education system; besides the factors, the most important role falls to the teacher (Erdaş, 2009). To prepare young people for their future roles, to protect them from bad habits and to save them, to improve their personalities, to educate them as good citizens, to discuss learning, to question, to raise a youth capable of producing science in almost every society is expected from the education system. To this end, teachers' job satisfaction, motivation, commitment to organizational culture and sense of belonging are important. Motivation levels are one of the most important factors that increase or decrease the work desires and job satisfaction of the individuals in the organizational environment. In the last quarter of the twenty-first century, workplace motivation has become one of the most important concepts in the study of various organizational behaviors. (De Rijk, Janssen, Van Lierop, Alexanderson \& Nijhuis, 2009).

The performance of teachers is also a priority in achieving the goals of the school. Performance is related to motivation of teachers in the work environment (Karadeniz \& Yavuz, 2009). Motivation is an important part of organizational behavior as a factor that directs human behavior in an organization and enables the emergence of human behavior (Örücü \& Kambur, 2008). Motivation is the power that supports and directly affects the performance of the employees (Özdemir \& Muradova, 2008; Littlejohn, 2008; Millette \& Gagne, 2008; Srinivasan, 2008).

Motivation and related to this subject; the teacher performance plays an important role in the effectiveness of schools. A principal who wants to develop performance should take into account the attitudes and behaviors of the employees, their desires and wishes, their ideas and feelings and the factors within and outside the organization that affect them. Motivation and, consequently, teacher performance play an important role in the effectiveness of schools. 
Work performance is considered as one of the most crucial factors for industrial and organizational psychology research and applications and is considered as a very important dependent variable. Performance, work performance and contextual performance can be considered in two dimensions. Work performance includes behaviors that support the technical foundations that produce or produce products or services. Work performance is directly related to carrying out technical processes, dealing with technical needs, and technical capabilities of the organization. The work performance is related to the expertise and the technical side of the job. Contextual performance includes volunteering for extra work, enthusiastically conducting business, cooperating with others, helping others, obeying rules, supporting and supporting the organization. Contextual performance is important for team success. Contextual performance is associated with extra role behavior in the organization (Van-Scotter \& Motowidlo, 1996).

The performance of the employees will affect the success of the organizations. The fact that the employees are able to perform and be productive depends on their satisfaction. The institutions should give importance to the factors that will increase the motivation of the employees in order to keep the work performance of the employees at the highest level and to decrease their absenteeism (Dysvik \& Kuvaas, 2011).

Non-motivated worker should not be expected to perform effectively and work efficiently. It is known that there is a meaningful relationship between work motivation and work performance in business life, increasing quality production activities and productivity. Therefore, the work performance and work motivations of the industrial workers will be determined and examined in terms of some variables.

Is there a meaningful difference in the work motivations and work performance of the workers according to their genders?

Is there a meaningful difference in job motivation and work performance according to the age variance of education workers? The answers will be searched out in this research.

\section{Method}

The research is a quantitative study in the relational survey model. The population of the study is composed of the Education Staff of İzmir Province. Totally 302 people, chosen with random method, participated into the study; 222, randomly selected, of them are male and 80 female education workers. 


\section{Data Collection Tools \\ Work Motivation Scale}

A work motivation scale consisting of 18 questions was developed by Aksoy (2006) and adapted by Tanriverdi (2007) used in the research. The structural validity of the business motivation scale was analyzed by factor analysis. According to the data obtained from the factor analysis, Kaiser-Meyer-Olkin

Sampling Measurement was found as 0,781. Therefore, the value of Bartlett olaraks Test of Sphericity is meaningful and it is $.470,77$. This result indicates that there is a relationship between the items of the scale. Work Motivation Scale consists of four sub-dimensions: 'Team cohesion' 'Business Integration' 'Commitment to the Institution' and 'Personal Development'.

\section{Work Performance Scale}

In this research, work performance inventory is benefited that is used to measure perceived organizational support and work performance. The scale consists of 16 articles and 1 article is the reverse coded question. There are two main dimensions of work performance in scale. In the scale $1,2,3,4,5,6,7,8,9$ numbered articles on the original scale related to role performance and out of-role (contextual) performance, 10,11, 12, 13, 14, 15, 16 numbered articles measure out of-role work performance. Kurt's (2013) Turkish version of the scale was used in our study.

\section{Findings}

Table 1. The $t$ Test results of work motivation sub dimensions related to genders of education workers

\begin{tabular}{|c|c|c|c|c|c|c|}
\hline Dimensions & Gender & $\mathbf{N}$ & $\mathbf{X}$ & Ss & $\mathbf{t}$ & p \\
\hline \multirow{2}{*}{$\begin{array}{l}\text { Team } \\
\text { Cohesion } \\
\end{array}$} & Male & 222 & 14,68 & 3,73 & \multirow{2}{*}{$-2,942$} & \multirow{2}{*}{,004 } \\
\hline & Female & 80 & 16,06 & 3,21 & & \\
\hline \multirow{2}{*}{$\begin{array}{l}\text { Integration } \\
\text { with work }\end{array}$} & Male & 222 & 14,64 & 3,70 & \multirow{2}{*}{$-1,705$} & \multirow{2}{*}{,089 } \\
\hline & Female & 80 & 15,46 & 3,60 & & \\
\hline \multirow{2}{*}{$\begin{array}{l}\text { Commitment } \\
\text { to Institution }\end{array}$} & Male & 222 & 11,21 & 3,08 & \multirow{2}{*}{$-3,034$} & \multirow{2}{*}{,003 } \\
\hline & Female & 80 & 12,38 & 2,56 & & \\
\hline \multirow{2}{*}{$\begin{array}{l}\text { Personal } \\
\text { Development }\end{array}$} & Male & 222 & 11,04 & 3,05 & \multirow{2}{*}{$-1,121$} & \multirow{2}{*}{,263 } \\
\hline & Female & 80 & 11,51 & 3,45 & & \\
\hline
\end{tabular}

$* \mathrm{p}<.05$ 
When the sub-dimensions of the Work Motivation Scale of the education workers were analyzed according to the gender, the arithmetical average of the male employees $(X=14.68)$ and the arithmetic average of the female employees $(X=$ 16.06) were found in the team cohesion sub-dimension. A meaningful difference was found between the averages $(\mathrm{t}=-2,942 \mathrm{p}>.05)$. In the work motivation of female employees, team cohesion levels were higher than male employees. When the integration of business sub-dimension was examined, the arithmetic average of male employees $(\mathrm{X}=14.64)$ and the arithmetic average of female employees was found as $(X=15.46)$. There was no meaningful difference between the averages $(t$ $=-1,705 \mathrm{p}>.05)$. When the sub-dimension of commitment is examined, the arithmetic average of male employees $(X=11,21)$ and the arithmetic average of female employees found as $(\mathrm{X}=12,38)$. A meaningful difference was found between the averages $(t=-3,034 \mathrm{p}>.05)$. The commitment of the female employees to the institution in the job motivation was higher than the male employees. When the personal development sub-dimension was examined, the arithmetic average of male employees $(X=11.04)$ and the arithmetic average of female employees $(X=11.51)$ were found. No meaningful difference was found between the averages $(\mathrm{t}=-1,121 \mathrm{p}>.05)$.

Table 2. The $t$ Test results of work motivation scale sub dimensions related to genders of education workers

\begin{tabular}{lllllll}
\hline Dimensions & Gender & N & X & Ss & t & p \\
\hline Duty & Male & 222 & 33,06 & 13,51 & \multirow{2}{*}{$\mathbf{3 , 3 5 3}$} & \multirow{2}{*}{, 001} \\
Performance & Female & 80 & 38,90 & 12,84 & & \multirow{2}{*}{, 775} \\
\hline Contextual & Male & 222 & 26,15 & 7,43 & \multirow{2}{*}{285} & \multirow{2}{*}{ Performance } \\
Female & 80 & 25,86 & 9,16 & & \\
\hline
\end{tabular}

When the sub-dimensions of the Work performance Scale of the education workers were analyzed depending on gender, the arithmetic average of the male employees $(\mathrm{X}=33,06)$ and the arithmetic average of female employees $(\mathrm{X}=$ $38,90)$ were examined. A meaningful difference was found between the averages $(t$ $=-3,353 \mathrm{p}>.05)$. The performance levels of the female employees in the performance of their jobs were higher than those of the male employees. When the contextual performance sub-dimension was examined, the arithmetic mean of male employees $(X=26,15)$ and the arithmetic mean of female employees $(X=25,86)$ were found. There was no meaningful difference found between the averages $(t=$, $285 \mathrm{p}>.05)$. 
Table 3. The F Test results of work motivation scale sub dimensions related to vocational experiences of education workers

\begin{tabular}{|c|c|c|c|c|c|c|}
\hline Dimensions & $\begin{array}{l}\text { Vocational } \\
\text { Experience }\end{array}$ & $\mathbf{N}$ & $\mathbf{X}$ & Ss & $\mathbf{F}$ & $\mathbf{P}$ \\
\hline \multirow{3}{*}{$\begin{array}{l}\text { Team } \\
\text { Cohesion }\end{array}$} & 1-10 Years & 92 & 14,27 & & \multirow{3}{*}{5,511} & \multirow{3}{*}{,004 } \\
\hline & 11-20 Years & 76 & 14,65 & 3,42 & & \\
\hline & 21 Years and over & 134 & 15,79 & 3,79 & & \\
\hline \multirow{3}{*}{$\begin{array}{l}\text { Integration } \\
\text { with Work }\end{array}$} & 1-10 Years & 92 & 14,16 & 3,90 & \multirow{3}{*}{12,716} & \multirow{3}{*}{,000 } \\
\hline & 11-20 Years & 76 & 13,69 & 3,52 & & \\
\hline & 21 Years and over & 134 & 16,00 & 3,31 & & \\
\hline \multirow{3}{*}{$\begin{array}{l}\text { Commitment } \\
\text { to Institution }\end{array}$} & 1-10 Years & 92 & 10,90 & 2,96 & \multirow{3}{*}{9,251} & \multirow{3}{*}{,000 } \\
\hline & $11-20$ Years & 76 & 10,85 & 2,96 & & \\
\hline & 21 Years and over & 134 & 12,33 & 2,86 & & \\
\hline \multirow{3}{*}{$\begin{array}{l}\text { Personal } \\
\text { Development }\end{array}$} & 1-10 Years & 92 & 10,10 & 3,23 & \multirow{3}{*}{14,504} & \multirow{3}{*}{,000 } \\
\hline & $11-20$ Years & 76 & 10,64 & 3,26 & & \\
\hline & 21 Years and over & 134 & 12,20 & 2,74 & & \\
\hline
\end{tabular}

$$
\text { *p<.05 }
$$

When the sub-dimensions of the Business Motivation Scale were examined according to the professional experiences of the training workers, meaningful differences were found in the sub-dimensions of team cohesion, job integration, commitment to the organization and personal development. Meaningfulness analysis was applied to determine which group was the difference in terms of the professional experience of the employees. Table 9 presents the findings of the Tukey Test to determine which groups differed according to their professional experience.

Table 4. The multiple comparison test results of work motivation scale sub dimensions of education workers related to differentiation from which group it was derived depending on their vocational experiences

\begin{tabular}{|c|c|c|c|c|c|}
\hline Dimensions & $\begin{array}{c}(\mathrm{I}) \\
\text { Vocational } \\
\text { Experience }\end{array}$ & $\begin{array}{l}\text { (J) Vocational } \\
\text { Experience }\end{array}$ & $\begin{array}{c}\begin{array}{c}\text { Difference } \\
\text { between } \\
\text { averages (I- } \\
\text { J) }\end{array} \\
\end{array}$ & SH & Sig. \\
\hline \multirow{3}{*}{ Team Cohesion } & \multirow[b]{2}{*}{ 1-10 Years } & 11-20 Years &,- 38616 &, 55 & ,768 \\
\hline & & $\begin{array}{l}21 \text { Years and } \\
\text { over }\end{array}$ & $-1,52677^{*}$ & ,48 &, 005 \\
\hline & 1-10 Years & 11-20 Years & ,46568 & ,55 & ,675 \\
\hline
\end{tabular}

Int.J. Hum. Soc. Dev. Res.

Volume 2, № 2, 2018.95-105 


\begin{tabular}{|c|c|c|c|c|c|}
\hline $\begin{array}{l}\text { Integration } \\
\text { work }\end{array}$ & & $\begin{array}{l}21 \text { Years and } \\
\text { over }\end{array}$ & $-1,83696^{*}$ &, 48 &, 000 \\
\hline \multirow{2}{*}{$\begin{array}{l}\text { Commitment } \\
\text { Institution }\end{array}$} & \multirow{2}{*}{$1-10$ Years } & $11-20$ Years & ,04691 & 45 & ,994 \\
\hline & & $\begin{array}{l}21 \text { Years and } \\
\text { over }\end{array}$ & $-1,43365^{*}$ & ,39 & ,001 \\
\hline \multirow{2}{*}{$\begin{array}{l}\text { Personal } \\
\text { Development }\end{array}$} & \multirow[b]{2}{*}{ 1-10 Years } & $11-20$ Years &,- 53604 &, 47 & ,491 \\
\hline & & $\begin{array}{l}21 \text { Years and } \\
\text { over }\end{array}$ & $-2,09280^{*}$ & ,41 &, 000 \\
\hline
\end{tabular}

$$
* \mathrm{p}<.0
$$

When the Job Motivation Scale scores were examined according to the professional experience of the training staff, the team cohesion was meaningfully higher in the team cohesion sub-dimension than in the professional experience of the employees between 1-10 years and 11-20 years and 21 years. In the subdimension of business integration, the team experience of the employees with a professional experience of 1 to 10 years was found to be meaningfully higher than those of 11-20 years and 21 years. In the sub-dimension of adherence to the institution, the professional experience of the employees with 1-10 years of experience was found to be meaningfully higher than those of 11-20 years and 21 years. In the sub-dimension of personal development, the professional experience of the employees with 1-10 years of experience was found as meaningfully higher than those of 11-20 years and 21 years over.

Tablo 5. The $F$ test results of work motivation scale sub dimensions of education workers if there is a difference or not according to their ages

\begin{tabular}{|c|c|c|c|c|c|c|}
\hline Dimensions & Age & $\mathbf{N}$ & $\mathbf{X}$ & Ss & $\mathbf{F}$ & $\mathbf{P}$ \\
\hline \multirow{3}{*}{$\begin{array}{l}\text { Duty } \\
\text { Performance }\end{array}$} & 20-30 Age & 98 & 29,29 & & \multirow{3}{*}{20,418} & \multirow{3}{*}{,000 } \\
\hline & 31-40 Age & 71 & 32,32 & 12,30 & & \\
\hline & 41 Age and over & 133 & 39,75 & 12,92 & & \\
\hline \multirow{3}{*}{$\begin{array}{l}\text { Contextual } \\
\text { Performance }\end{array}$} & 20-30 Age & 98 & 23,63 & 7,88 & \multirow{3}{*}{$\mathbf{8 , 8 2 9}$} & \multirow{3}{*}{,000 } \\
\hline & 31-40 Age & 71 & 25,95 & 7,36 & & \\
\hline & 41 Age and over & 133 & 27,94 & 7,77 & & \\
\hline
\end{tabular}

When the sub-dimensions of the Work performance Scale were analyzed according to the age of the employees, meaningful differences were found in the subdimensions of work performance and contextual performance. Significance 
analysis was conducted in order to determine the difference that from which group it was derived according to the age of the employees.

Table 6. The multiple test results of work performance scale sub dimensions of education workers related to difference from which group it was derived from according to their ages

\begin{tabular}{llllll}
\hline Dimensions & (I) Age & (J) Age & $\begin{array}{l}\text { Difference } \\
\text { between } \\
\text { averages } \\
\text { J) }\end{array}$ & (I- SH & Sig. \\
\hline $\begin{array}{l}\text { Duty } \\
\text { Performance }\end{array}$ & $20-30$ Yaş & 31-40 Age & $-3,02803$ & 1,98 &, 282 \\
& & 41 Age and over & $-\mathbf{1 0 , 4 5 5 9 6 *}$ & 1,69 &, 000 \\
\hline $\begin{array}{l}\text { Contextual } \\
\text { Performance }\end{array}$ & \multirow{2}{*}{$20-30$ Yaş } & 31-40 Age & $-2,32509$ & 1,20 &, 131 \\
& & 41 Age and over & $-\mathbf{- 4 , 3 1 4 7 2}^{*}$ & 1,02 &, 000 \\
\hline
\end{tabular}

$* \mathrm{p}<.05$

According to the age variances of the employees, the performance scores of the employees between the ages of 20 and 30 were higher than those between the ages of 31-40 and 41 years. When the contextual performance levels are examined, the performance levels of the industrial workers between the ages of 20 and 30 are higher than those of the age group 31-40 and over 41 years.

\section{Discussion}

'Is there a meaningful difference in the work motivation of the education staff according to the gender variable?' When the findings of the question were examined, it was found that female employees' team cohesion and adherence levels were higher than male employees. Y1ldiz (2010) found that the satisfaction level of female teachers in intrinsic motivation factors is higher than the satisfaction level of male teachers. Chang, (2003) showed that the effect of gender does not affect the level of motivation. When the related literature is examined, the research findings are not supported. "Is there a meaningful difference in the work performance of the education workers according to the gender variable?" stated that they are among the factors affecting their performance. In the study of Baysal and Paksoy (1999) they expressed that gender is among the factors that has an effect on performances of the workers. The research findings are supported by the related literature. 
'Are there any meaningful differences in the motivation of the employees according to the age variable of the training?' As a result of this question when the findings of the research were examined, the motivation of the teachers working in primary schools varies meaningfully according to the age of teachers. The highest motivation is teachers in the age group of 22-30, and the lowest motivation is teachers in the 41-50 age groups. As the age progresses, the motivation levels of the teachers also decrease. When the related literature is examined, it is parallel with this finding of the research. The research findings are covered with the findings that were done by Aksoy (2006), Tiryaki (2008), Tanrıverdi (2007) and Y1lmaz (2013). According to the findings of these studies, the motivation level of the teachers does not differ according to age.

In a research for bringing out the relationship between employees' ages and performances, it was seen that young employees produced higher levels of work, whereas younger workers produced higher-quality jobs (Jun \& Huang, 2007). And it causes low performance. The most proper example of this situation can be given by professional athletes. The progress of age in performance-based jobs is expressed as a negative factor. In the works where the mind power is used more, it is seen that the age is advanced. These results support the findings of the study.

\section{Disclosure statement}

No potential conflict of interest was reported by the author.

\section{Contact Information}

E-mail: yozcan@yahoo.com 


\section{References and notes:}

Aksoy, H. (2006). Effect of the organization atmosphere to the motivation. Master Thesis, Marmara Univeristy E.A.S.F. Journal, 15(2) 25-35.

Baysal, A. \& Paksoy, M. (1999). Meyer-Allen model in a multi-aspected study of commitment to the work and organization, Istanbul University Journal of Faculty of Business, 28 (1), 7-15.

Danış, A. (2009). Organizational commitment levels of Anatolian technical and Anatolian vocational high school teachers. Master's thesis, Yeditepe University Institute of Social Sciences, Istanbul.

De Rijk, A., Janssen, N., Van Lierop, B., Alexanderson, K., \& Nijhuis, F. A. (2009). Behavioral approach to RTW after sickness absence: The development of instruments for the assessment of motivational determinants, motivation and key actors' attitudes. Work, 33, 273-285.

Dysvık, A. \& Kuvaas, B. (2011). Intrinsic motivation as a moderator on the relationship between perceived job autonomy and work performance. European Journal of Work and Organizational Psychology, 20(3), 367-387.

Erdaş, Y. (2009). Organizational commitment levels of primary school teachers working in Denizli city center. Master Thesis, Denizli: Pamukkale University Institute of Social Sciences.

Iun, J. \& Huang, X., (2007). How to motivate your older employees to excel? the impact of commitment on older employees' performance in the hospitality industry, International Journal of Hospitality Management, 26 (4), 793-806.

Karadeniz, B. C. \& Yavuz, C. (2009). The effect of the motivation of classroom teachers on job satisfaction. International Journal of Social Researches, 2 (9), 507-509.

Kurt, E. (2013). The impact of job dependence on perceived social support and business performance: A research in tourism enterprises, Master Thesis, Hacettepe University, Institute of Social Sciences, Department of Business Administration, Ankara.

Littlejohn, A. (2008). The tip of the iceberg: Factors affecting learner motivation. Regional Language Centre Journal, 39(2), 214-225.

Millette, V. \& Gagne, M. (2008). Designing volunteers' works to maximize motivation, satisfaction and performance: the impact of job characteristics on volunteer engagement. Motivation and Emotion, 32(1), 11-22.

Örücü, E. \& Kambur, A. (2008). An empirical study to examine the effects of organizational-managerial motivation factors on the performance and efficiency of employees: an example of service and industrial enterprise. Management and Economics, 15 (1), 85 ,97.

Özdemir, S. \& Muradova, T. (2008). The relationship between motivation and productivity in organizations. Journal of Qafqaz University, 24, 146-153.

Öztürk, T. (2006). The factors that increase and maintain motivation of primary school teachers (Kağıthane-Levent Application). Master Thesis, Istanbul Beykent University Institute of Social Sciences.

Recepoğlu, E. (2013). Investigation of Teachers' Motivations in terms of Different Variables. Kastamonu Education Journal, 21 (2), 575-588. 
Srinivasan, M.S. (2008). Motivation and human growth: A developmental perspective. Journal of Human Values, 14 (1), 63-71.

Tanriverdi, S. (2007). A sample study on the relationship between participatory school culture and foreign language teachers' work motivation, Master Thesis, Yeditepe University Institute of Social Sciences, Istanbul.

Van-Scotter, J.,\& Motowidlo, S. J. (1996). Interpersonal facilitation and job dedication as separate facets of contextual performance. Journal of Applied Psychology, 81, 525-31.

Y1lmaz, M. (2013). The “ÖNKAS” Reward System for The Enhancement of Teachers' Motivation . Uşak University Social Sciences Journal, Private Volume, 286-306. 